\title{
Olanzapine Penetration into Brain is Greater in Transgenic Abcb /a P-glycoprotein-Deficient Mice than FVBI (Wild-Type) Animals
}

\author{
Jun-Sheng Wang', Robin Taylor', Ying Ruan', Jennifer L Donovan', John S Markowitz ${ }^{2}$ and \\ C Lindsay De Vane*, I \\ 'Laboratory of Drug Disposition and Pharmacogenetics, Department of Psychiatry and Behavioral Sciences, Medical University of South Carolina, \\ Charleston, SC, USA; ${ }^{2}$ Department of Pharmaceutical Sciences, Medical University of South Carolina, Charleston, SC, USA
}

\begin{abstract}
The transmembrane energy-dependent efflux transporter P-glycoprotein (P-gp) limits a range of drugs from penetrating cells and deposits them into the extracellular space. P-gp is highly expressed in several normal tissues, including the luminal surface of capillary endothelial cells in the brain of humans. In this study, we tested whether olanzapine distribution to tissues highly expressing P-gP or devoid of this transporter was similar in Abcb I a (-/-) mice lacking P-gp and control animals. At I h following the intraperitoneal injection of $2.5 \mu \mathrm{g}$ olanzapine/g mouse, olanzapine concentrations were statistically and significantly higher in brain (three-fold), liver (2.6-fold), and kidney (I.8-fold) of Abcb / a (-/-) mice than those of the control FVB Abcbla $(+/+)$ mice, and not statistically different in plasma, spleen, or penile tissue. Similar differences were also found for the ratios of organ:plasma and organ:spleen between the two groups. This is the first report that the presence of the $A b c b / a$ gene is an important factor controlling brain access to olanzapine. The finding that the brain penetration of olanzapine is limited by P-gp implies that the highly prevalent functional polymorphisms of $A B C B /$ in humans may be a factor contributing to variability in dose requirements for this antipsychotic drug.

Neuropsychopharmacology (2004) 29, 55 I-557, advance online publication, 3 I December 2003; doi: I 0.I 038/sj.npp. I 300372
\end{abstract}

Keywords: olanzapine; P-glycoprotein; MDRI; ABCBI; blood-brain barrier

\section{INTRODUCTION}

The adenosine triphosphate (ATP)-binding cassette (ABC) superfamily of efflux transport proteins contains subfamily $\mathrm{B}$, often referred to as the multidrug-resistant subfamily (MDR), and subfamily $\mathrm{C}$, also known as the multidrugresistant related protein subfamily (MRP) (Germann, 1996; Carson et al, 2002). The most extensively studied $\mathrm{ABC}$ transporter is P-glycoprotein (P-gp). P-gp belongs to subfamily $B$ and is a $170-\mathrm{kDa}$ transmembrane protein encoded by the human gene $A B C B 1$. Formerly known as MDR1 or PGY1, ABCB1 maps to chromosome 7q21.1 (Dean et al, 2001). It was the first $\mathrm{ABC}$ transporter cloned and characterized by its ability to confer a multidrug resistance phenotype to cancer cells that had become resistant to chemotherapy (Riordan et al, 1985; Roninson et al, 1986).

\footnotetext{
*Correspondence: CL DeVane, Institute of Psychiatry, Medical University of South Carolina, 67 President Street, Charleston, SC 49425, USA, Tel: + I-843-792-5448, Fax: + |-843-792-6318,

E-mail: devaneL@musc.edu

Received I4 March 2003; revised 28 October 2003; accepted 24 November 2003

Online publication: 26 November 2003 at http://www.acnp.org/ citations/Npp | | 260303 |06/default.pdf
}

In addition to expression in tumor cells, the $A B C B 1$ protein (P-gp) is widely localized in normal tissues, including the apical membranes of the gastrointestinal tract, the biliary canalicular membranes of hepatocytes, the luminal membranes of proximal tubular epithelial cells in the kidney, and the luminal membranes of endothelial cells in cerebral capillaries forming the blood-brain barrier (Cordon-Cardo et al, 1989; Yu, 1999; Silverman, 2000).

The biological function of P-gp appears to be a protective role for major organs by limiting cellular uptake of xenobiotics by excreting these compounds into bile, urine, the intestinal lumen, and limiting accumulation in brain. This function as a drug efflux pump plays an important role in drug absorption, distribution, and elimination (Lin and Yamazaki, 2003). A large number of structurally diverse drugs from various pharmacologic classes are actively transported by P-gp (Schinkel et al, 1996; Schuetz et al, 1996; Mahar Doan et al, 2002; Weiss et al, 2003). P-gp is highly polymorphic and its expression in the endothelial cells of the blood-brain barrier limits substrate access to the central nervous system (CNS), thereby influencing the therapeutic consequences of psychoactive drugs (Thompson et al, 2000). A P-gp inhibitor was shown to increase the extracellular fluid concentration of morphine in the brain of 
rats, while chronic treatment with morphine leading to tolerance of the antinociceptive effect was shown to be mediated by a morphine-induced increase in the brain P-gp (Aquilante et al, 2000).

Several in vitro cell systems and a transgenic $A b c b 1 a / b(-/-)$ mouse model have been used to study the functional activity of the protein in the blood-brain barrier (Lin and Yamazaki, 2003; Schwab et al, 2003). Drug-stimulated ATPase activity can be determined by monitoring the release of inorganic phosphate (Sarkadi et al, 1992; Urbatsch et al, 1994). Alternatively, fluorescent indicators can be monitored where the inhibition of P-gp leads to cellular accumulation of rhodamine-123 or calcein AM (Eytan et al, 1997; Tiberghien and Loor, 1996). The Abcb1a(-I-) 'knockout' mouse model exhibits functional deficiency of P-gp in the blood-brain barrier (CordonCardo et al, 1989; Schinkel et al, 1996, 1997; Silverman, 2000 ), and therefore has provided considerable insight into the role and importance of P-gp in the brain entry of drugs (Kim et al, 1998; Schinkel et al, 1996, 1997; Letrent et al, 1999; Aquilante et al, 2000). Mice lacking the Abcb1a gene display no anatomical, biochemical, or other abnormalities (Schinkel et al, 1994, 1997).

Data documenting transport of antipsychotic drugs with P-gp are sparse. No previous reports could be found using the Abcbla (-I-) mouse to test antipsychotic drugs for transport by P-gp. Previous reports using in vitro methods have found that levomeprazine and risperidone may be substrates, while chlorpromazine, clozapine, haloperidol, chlorprothixene, and perphenazine may not (Mahar Doan et al, 2002; Schinkel et al, 1997). The data on chlorpromazine are conflicting with positive transport using the human CCRF-CEM leukemia cells (Syed et al, 1996) and low transport by multidrug resistance-transfected MDCK cells (Mahar Doan et al, 2002). Using ATPase activity as a marker for P-gp binding affinity, we previously found a rank order of activity from verapamil (positive control) $>$ quetiapine $>$ risperidone $>$ olanzapine $>$ chlorpromazaine $>$ haloperidol=clozapine (Boulton et al, 2002). These results suggested that P-gp may influence the access to the brain of the antipsychotics to various degrees.

Verapamil, quetiapine, and risperidone each are partially metabolized by CYP3A4 (Kroemer et al, 1993; DeVane and Nemeroff, 2001a, b). Olanzapine is predominantly biotransformed by CYP1A2 and glucuronyl transferases, yet a small contribution by CYP3A4 has been implicated (Ring et al, 1996; Markowitz et al, 2001). An inter-relationship in substrate specificity between cytochrome P450 (CYP) 3A4 and P-gp has been proposed (Kim et al, 1999). The ABCB1 and CYP $3 A$ genes are located on the same chromosome with proximal gene loci in humans (Tsui et al, 1995); however, many drugs that are CYP3A4 substrates (midazolam, triazolam, alprazolam) are not transported by P-gp and vice versa (digoxin, fexofenadine; Perloff et al, 1999; Schuetz et al, 1996; von Moltke et al, 1999). Nevertheless, the overlap in CYP3A4 and P-gp substrates is consistent with our previous in vitro results based on ATPase activity, suggesting that quetiapine among the antipsychotics had the greatest degree of affinity for P-gp (Boulton et al, 2002). Olanzapine has the least evidence as a P-gp substrate. To further assess the role of P-gp in limiting brain entry of the antipsychotics, we compared the tissue distribution of olanzapine in $A b c b 1 a(-/-)$ transgenic mice with that in the FVB control Abcbla $(+I+)$ mice.

\section{MATERIALS AND METHODS}

\section{Chemicals}

Olanzapine and RS0244 (internal standard) were obtained from Eli Lilly Inc. (Indianapolis, ID, USA). Hank's balanced salt solution (HBSS) was purchased from Gibco BRL (Carlsbad, CA, USA). Other chemicals and reagents were the purest grade available and were obtained from Fisher Scientific Co. (Fairlawn, NJ, USA).

\section{Experimental Animals}

Male Abcb1a (-/-) mice (FVB/TacfBR-[KO]MDR1aN7) and genetically matched male Abcbla $(+/+)$ mice (FVB/ MTtacfBR) 9-10 weeks of age weighing 20-30g were obtained from Taconic (Germantown, NY, USA). The founding of this colony has been described previously (Schinkel et al, 1994). Animals were housed individually and maintained at a 12:12 h light/dark cycle. The animals were cared for in accordance with the US Public Health Service policy for the Care and Use of Laboratory Animals, and the experimental studies were approved by the Medical University of South Carolina Animal Care Committee.

\section{Experimental Procedures}

Olanzapine was dissolved in $0.9 . \%$ saline with minimal use of $1 \mathrm{~N} \mathrm{HCL}(1 \%, \mathrm{v} / \mathrm{v})$. A dose of $2.5 \mu \mathrm{g}$ olanzapine/g mouse was administered intraperitoneally (i.p.). The entire volume injected was $10 \mu \mathrm{l} / \mathrm{g}$ mouse. At $1 \mathrm{~h}$ after the injection, the mice were anesthetized with halothane and decapitated. Trunk blood was collected in EDTA-coated tubes and centrifuged at $3000 \mathrm{~g}$ for $20 \mathrm{~min}$ to determine plasma concentrations of olanzapine.

The brain (brain tissue plus meninges), liver, kidney, spleen, and penis were dissected and weighed, and then homogenized in five-fold volume of an HBSS and $0.02 \mathrm{M}$ HEPES buffer, $\mathrm{pH}$ 7.2. The homogenates were frozen at $-70^{\circ} \mathrm{C}$ until high-performance liquid chromatography (HPLC) analysis.

\section{HPLC Analysis of Olanzapine Plasma and Tissue Concentrations}

The plasma and tissue samples obtained at $1 \mathrm{~h}$ following administration of olanzapine were extracted and determined using HPLC method previously developed and validated in our laboratory and modified for tissue samples (Boulton et al, 2001; Llorca et al, 2001). Briefly, olanzapine was extracted from 100 or $200 \mu \mathrm{l}$ of plasma or organ samples after the addition of $50 \mu \mathrm{l}$ of internal standard working solution (RS0244 $10 \mu \mathrm{g} / \mathrm{ml}$ ), $0.2 \mathrm{ml}$ of $1 \mathrm{M}$ bicarbonate buffer (pH 11), and $5 \mathrm{ml}$ of a mixture of hexane-isoamyl alcohol $(98: 2, \mathrm{v} / \mathrm{v})$. The mixture was shaken for $15 \mathrm{~min}$ and centrifuged at $3000 \mathrm{~g}$ for $5 \mathrm{~min}$. The organic layer was transferred to another tube and back-extracted with $0.2 \mathrm{ml}$ $0.2 \mathrm{M}$ sulfuric acid. After shaking and centrifugation, the aqueous layer was re-extracted with $0.2 \mathrm{ml}$ of $1 \mathrm{M}$ bicarbonate 
buffer. The organic phase was evaporated under nitrogen at $45^{\circ} \mathrm{C}$. The residue was dissolved in $100 \mu \mathrm{l}$ of mobile phase (65\% methanol:35\% water containing $0.2 \%$ triethylamine and was adjust to $\mathrm{pH} 7.0$ with $85 \%$ phosphoric acid), and $50 \mu \mathrm{l}$ was injected into the chromatographic system. Olanzapine and internal standard were separated by a Luna $5 \mathrm{u} \mathrm{C18}(2)$ column $(250 \times 4.6 \mathrm{~mm}$; Phenomenex $)$, and the effluent was monitored at a UV wavelength of $273 \mathrm{~nm}$ and at a flow rate of $1 \mathrm{ml} / \mathrm{min}$ at ambient temperature. The detection limit of olanzapine was $5 \mathrm{ng} / \mathrm{ml}$. The intraday and interday coefficients of variation were lower than $7 \%$ at relevant concentrations $(n=7)$. The plasma and tissue extraction recoveries ranged from 83 to $98 \%$.

\section{Data Analysis}

Drug quantitation was performed by comparing peak height ratios of olanzapine to the internal standard with ratios derived from calibration curve of standards containing known amounts of drug extracted from plasma or tissues as described above. Final concentrations of olanzapine were expressed as either $\mu \mathrm{g} / \mathrm{ml}$ for plasma or $\mu \mathrm{g} / \mathrm{g}$ for tissues.

An unpaired $t$-test was used to compare the differences between the concentrations of olanzapine in the Abcb1a(-/-) mice and control mice and their tissue:plasma and tissue:spleen ratios. A two-tailed $P$-value was used and the level of statistical significance was $P<0.01$.

\section{RESULTS}

The plasma and organ concentrations of olanzapine $1 \mathrm{~h}$ after the i.p. injection of $2.5 \mu \mathrm{g}$ olanzapine/g mouse are shown in Table 1 and Figure 1. Substantially and statistically higher olanzapine concentrations were found in the brain (three-fold), liver (2.6-fold), and kidney (1.8-fold) of Abcb1a(-I-) mice than those of the control mice (Table 1, Figure 1). Consistently higher ratios were also found for the organ:plasma and the organ:spleen concentrations of olanzapine in the $A b c b 1 a(-/-)$ mice than in the control mice (Table 1, Figure 2). However, there was no statistically significant difference for concentrations of olanzapine in the plasma, spleen, and penis between the two groups, nor for the tissue:plasma ratios of spleen and penis (Table 1, Figures 1 and 2).

\section{DISCUSSION}

The current findings demonstrate that the brain penetration of olanzapine is limited by P-gp. The three-fold difference in the brain concentration of olanzapine between the P-gpdeficient $A b c b 1 a(-/-)$ mice and the FVB control $A b c b 1 a(+/+)$ mice were most likely due to the functional activity of $\mathrm{P}$-gp residing in the blood-brain barrier. This conclusion is also in good agreement with the 2.6-fold difference observed in brain:plasma and brain:spleen ratios of olanzapine between the two groups, indicating that the difference in the brain olanzapine concentration between the two groups was not caused by differences of plasma olanzapine concentration that were identical. Similarly, differences in concentration in the spleen were absent, since the expression of P-gp in the spleen is very low (Cordon-
Table I Tissue Concentrations and Tissue:Plasma Ratios of Olanzapine in Abcb/a(-/-) $(n=6)$ and Wild-Type Mice $(n=6)$ after I h i.p. Injection of Olanzapine $2.5 \mu \mathrm{g} / \mathrm{g}$ Mouse

\begin{tabular}{lcccc}
\hline & $\begin{array}{c}\text { Abcbla(-I-) } \\
\text { (mean } \pm \text { SD) }\end{array}$ & $\begin{array}{c}\text { Wild type } \\
\text { (mean } \pm \text { SD) }\end{array}$ & Ratio $^{\mathbf{a}}$ & $\begin{array}{c}\text { P-value } \\
\text { (unpaired t-test) }\end{array}$ \\
\hline Plasma & $0.6 \pm 0.1$ & $0.6 \pm 0.1$ & 1.1 & 0.5 \\
Brain & $1.3 \pm 0.3$ & $0.5 \pm 0.2$ & 3.0 & $0.0006^{*}$ \\
Liver & $3.5 \pm 0.6$ & $1.5 \pm 0.6$ & 2.6 & $0.0002^{*}$ \\
Kidney & $2.8 \pm 0.7$ & $1.5 \pm 0.2$ & 1.8 & $0.002^{*}$ \\
Spleen & $3.1 \pm 0.9$ & $3.1 \pm 0.3$ & 1 & 0.9 \\
Penis & $0.5 \pm 0.3$ & $0.6 \pm 0.3$ & 0.9 & 0.5 \\
Brain:plasma & $2.0 \pm 0.5$ & $0.9 \pm 0.4$ & 2.6 & $0.002^{*}$ \\
Liver:plasma & $5.5 \pm 1.2$ & $2.5 \pm 0.8$ & 2.4 & $0.0005^{*}$ \\
Kidney:plasma & $4.4 \pm 1.3$ & $2.6 \pm 0.1$ & 1.7 & $0.006^{*}$ \\
Spleen:plasma & $4.7 \pm 1.0$ & $5.2 \pm 1.0$ & 0.9 & 0.5 \\
Penis:plasma & $0.8 \pm 0.5$ & $1.0 \pm 0.3$ & 0.9 & 0.4 \\
Brain:spleen & $0.5 \pm 0.2$ & $0.2 \pm 0.1$ & 2.6 & $0.009^{*}$ \\
Liver:spleen & $1.2 \pm 0.5$ & $0.5 \pm 0.2$ & 2.4 & $0.007^{*}$ \\
Kidney:spleen & $1.0 \pm 0.4$ & $0.5 \pm 0.1$ & 1.7 & $0.02^{*}$ \\
Penis:spleen & $0.2 \pm 0.1$ & $0.2 \pm 0.05$ & 0.9 & 0.9 \\
\hline Calculat & & & & \\
\hline
\end{tabular}

${ }^{a}$ Calculated as the average of the ratios from each individual animal.

* Statistical significance $(P<0.01)$ by two-tailed unpaired $t$-test.

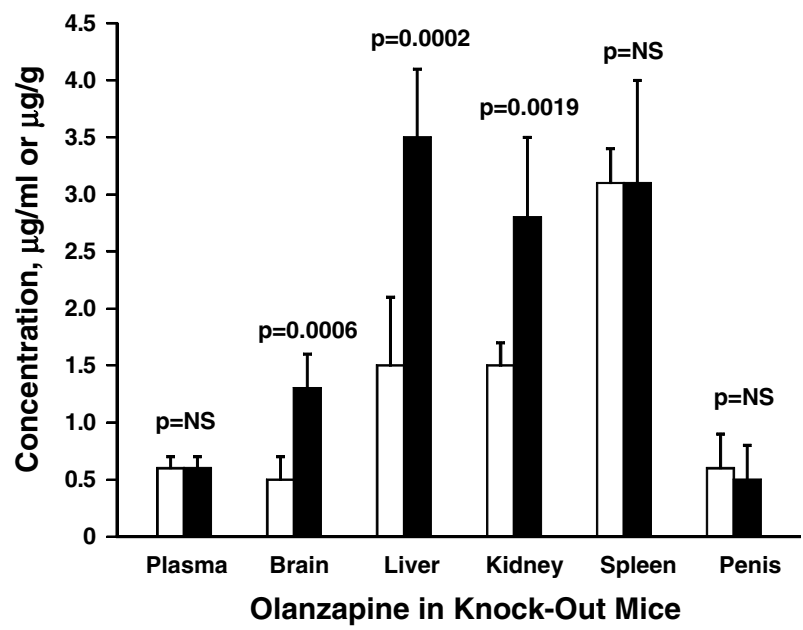

Figure I Plasma $(\mu \mathrm{g} / \mathrm{ml})$ and tissue $(\mu \mathrm{g} / \mathrm{g})$ concentrations of olanzapine in $A b c b / a(-/-)$ (solid bars) and Abcb/a $(+/+)$ mice (open bars) I h after the i.p. injection of $2.5 \mu \mathrm{g}$ olanzapine/g mouse. Values are shown as mean \pm SD $(n=6)$. The $P$-values shown were calculated by two-tailed unpaired t-test.

Cardo et al, 1989; Schinkel et al, 1997). These findings of no drug concentration differences in organs with low P-gp expression (plasma and spleen) are consistent with the previous results of Uhr et al (2000) using amitriptyline.

Previously, the absence of P-gp in $A b c b 1 a(-/-)$ mice has been shown as a pervasive influence on the tissue distribution and pharmacokinetics of drugs such as indinavir, nelfinavir, saqunavir, loperamide, ondansetron, ivermectin, vinblastin, cyclosporin A, amitriptyline, morphine, some endogenous steroid hormones, citalopram, trimipramine, carbamazepine, phenobarbital, lamotrigine, 


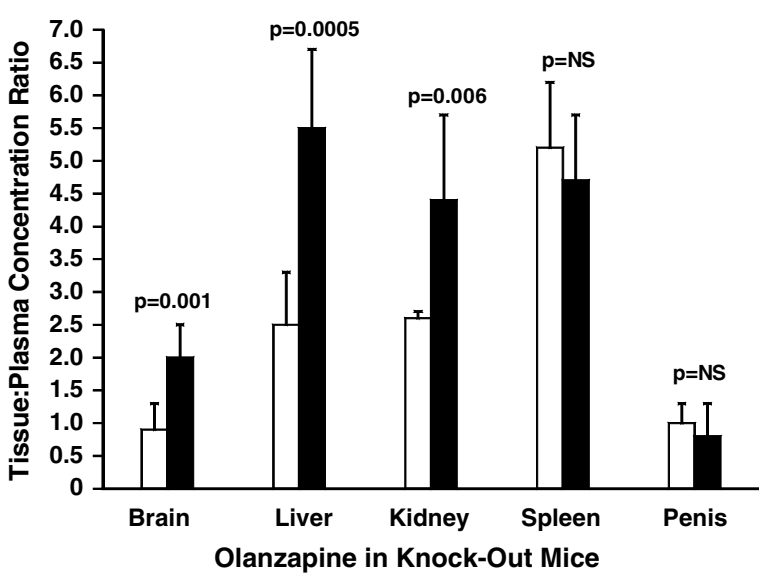

Figure 2 Organ:plasma ratios of olanzapine in Abcb/a (-/-) (solid bars) and $A b c b / a(+I+)$ mice (open bars) I h after the i.p. injection of $2.5 \mu \mathrm{g}$ olanzapine/g mouse. Values are shown as mean \pm SD $(n=6)$. The $P$-values shown were calculated by two-tailed unpaired $t$-test.

and felbamate (Kim et al, 1998; Schinkel et al, 1996, 1997; Letrent et al, 1999; Aquilante et al, 2000; Uhr et al, 2000, 2002; Fromm, 2000; Potschka et al, 2001, 2002; Uhr and Grauer, 2003). The brain concentrations of these drugs were remarkably higher in $A b c b 1 a(-/-)$ mice than that of Abcbla $(+I+)$ mice. However, differences in the liver and kidney were smaller compared to those in the brain or not statistically significant. In the present study, similar ratios of olanzapine to plasma were found for the brain, liver, and kidney $(3.0,2.6,1.8$, respectively, Table 1$)$ in $A b c b 1 a(-I-)$ compared to Abcb1a $(+I+)$ mice. When studies have found large differences in the brain concentration of drugs transported by P-gp in $A b c b 1 a(-/-)$ animals compared to controls, the liver and kidney differences in drug concentration were frequently small, but for some drugs (experimental anticonvulsants and doxorubicin; Van Asperen et al, 1999; Cox et al, 2002) such differences have been substantial. The exact mechanism(s) for this inconsistency between study results is unclear, but it suggests that the tissue distribution of drugs transported by P-gp in the two animal groups is highly dependent upon the specific substrate involved. Nevertheless, there is consistency in our results that statistically significant differences in drug concentrations were found in tissues normally containing P-gp (brain, liver, kidney), while no differences in concentrations were found in those tissues devoid of P-glycoprotein (plasma, spleen, and penis).

Olanzapine is one of the most widely used antipsychotic agents that has been marketed post clozapine. It is a serotonin/dopamine antagonist that has proven efficacy against both the positive and negative symptoms of schizophrenia, and is widely used in other psychotic disorders (Bhana et al, 2001). It has a markedly better side-effect profile than older conventional agents such as haloperidol and chlorpromazine (Beasley et al, 1996). However, even with these improvements, not all patients respond adequately to olanzapine and dosage requirements vary widely. Approximately $20-30 \%$ of patients with schizophrenia show an inadequate efficacy and $5-10 \%$ are intolerant to olanzapine therapy (Bhana et al, 2001).
The exact reason for refractory symptoms in olanzapinetreated patients is unknown. However, recent findings of functional polymorphisms of $A B C B 1$ in humans may provide an insight into one mechanism (Hoffmeyer et al, 2000). Single-nucleotide polymorphisms (SNP) in exon 26 (C3435T) and exon 21 (G2677T) have been associated with the functional activity of P-gp. The homozygous T/T genotype mutant alleles were associated with more than two-fold lower intestinal P-glycoprotein expression levels and higher bioavailability of digoxin, a prototype P-gp probe (Kurata et al, 2002; Nakamura et al, 2002). High frequencies of the mutant alleles are present in the population (19\% for the T/T 3435 allele and $28 \%$ for the T/T2677 allele; Lin and Yamazaki, 2003). These functional SNPs of P-gp in humans may represent a major source of interindividual variability in the therapeutic efficacy and toxicity of P-gp substrates. This effect may be even more remarkable for psychoactive drugs, which need to penetrate through the P-gp residing in the blood-brain barrier to exert their desirable pharmacological effects. Quite recently, Siddiqui et al (2003) reported that the ABCB1 C3435T polymorphism was associated with drug responses of epilepsy. Patients with drug-resistant epilepsy were more likely to have the CC genotype at ABCB1 3435 than the TT genotype compared with patients with drug-responsive epilepsy. In addition, the homozygosity for 3435T alleles of $A B C B 1$ has been suggested as a risk factor for the occurrence of nortriptyline-induced postural hypotension, a CNS side effect related to the protective role of P-gp in the brain penetration of nortriptyline (Roberts et al, 2002). Accordingly, it is conceivable that patients who have a high P-gp expression in their blood-brain barrier may have low brain concentrations of olanzapine contributing to therapeutic resistance or failure, and patients who have a low P-gp expression in their blood-brain barrier may have a relatively high brain olanzapine concentration, resulting in adverse events, toxicity, or beneficial therapeutic effects with lower than usual daily drug doses.

Previous studies have indicated that the modulation of P-gp-mediated drug transport can dramatically increase or decrease drugs' penetration into the CNS and affect their therapeutic efficacy (Letrent et al, 1999; Aquilante et al, 2000). For example, the analgesic effect of morphine in rats was enhanced through the use of a specific P-gp inhibitor (Letrent et al, 1999). Accordingly, the current experimental findings provide a rational for the potential use of P-gp modulators with olanzapine or other P-gp substrates, since a reversal of the functional activity of P-gp may result in improved therapeutic efficacy by increasing CNS drug concentration. However, the inhibition of P-gp activity in humans would likely increase both plasma and brain concentrations of olanzapine and other orally administered substrates, since P-gp is also present in the gastrointestinal tract (Fricker and Miller, 2002; Verstuyft et al, 2003; Becquemont et al, 2001; Hennessy et al, 2002). This is not necessarily a deterrent for the use of safe P-gp inhibitors. By artificially increasing the brain:plasma drug concentration ratio through the inhibition of P-gp, smaller oral substrate doses could be used resulting in lower plasma drug concentration, while maintaining an equivalent or higher concentration in the CNS. Adverse events related to systemic drug exposure should be decreased as a result of 
using lower oral doses while promoting increased efficacy at the site of action as a result of increased brain drug concentration. Such an approach is currently being investigated to improve the therapeutic efficacy of the protease inhibitors (Choo et al, 2000). A requisite step to applying this approach in neuropsychopharmacology is the identification of relevant P-gp substrates.

By measuring P-gp ATPase activity, we previously reported that the antipsychotics have various degrees of binding affinity with P-gp in vitro, with rank order of affinity (by measuring $V_{\max } / K_{\mathrm{m}}$ ) as: quetiapine $(1.7)>$ risperidone (1.4)> olanzapine $(0.8)>$ chlorpromazine $(0.7)>$ haloperidol $(0.3)=$ clozapine (0.3) (Boulton et al, 2002). Accordingly, olanzapine was identified as an intermediate affinity substrate among the antipsychotics (Boulton et al, 2002). Consistent with the present findings, a previous report using monolayer efflux in multidrug resistencetransfected cells identified that cellular uptake of risperidone is mediated by P-gp (Mahar Doan et al, 2002). In another study, the conventional antipsychotic chlorpromazine has been shown to be actively transported by P-gp in cancer-derived cells (Syed et al, 1996). Unfortunately, binding studies and in vitro transport measurements in monolayer cell systems under-represent the complexity of the in vivo situation. Inconsistencies have been noted (Polli et al, 2001). This is the first report using an in vivo model to identify that the brain entry of olanzapine is limited by Pgp. Unfortunately, no chemical, clinical, or pharmacological properties appear to allow accurate predictions within or between drug classifications of those compounds that are transported by P-gp. Even the widely used in vitro methods to evaluate transport have produced conflicting findings with approximately half of the studied compounds displaying significant variation in P-gp activity dependent on the specific assay used (Adachi et al, 2001; Yamazaki et al, 2001). The single and double knockout mouse model appears to produce the most unequivocal results (Schinkel et al, 1996).

In conclusion, the present results showed that the expression of P-gp in the blood-brain barrier significantly limits the penetration of olanzapine into the CNS. Functional polymorphisms of P-gp in humans may represent an unrecognized source of interindividual variability in the therapeutic efficacy of olanzapine. The recognition of brain entry of olanzapine is limited by P-gp offering intriguing possibilities for manipulating its therapeutic utility through the use of adjunctive P-gp modulators.

\section{ACKNOWLEDGEMENTS}

This work was partly supported by Public Health Service Grant DA-13027. None of the authors has conflicting interests that interfere with the integrity of the content of the article.

\section{REFERENCES}

Adachi Y, Suzuki H, Sugiyama Y (2001). Comparative studies on in vitro methods for evaluating in vivo function of MDR1 Pglycoprotein. Pharmacol Res 18: 1660-1668.
Aquilante CL, Letrent SP, Pollack GM, Brouwer KL (2000). Increased brain P-glycoprotein in morphine tolerant rats. Life Sci 64: 47-51.

Beasley Jr CM, Tollefson G, Tran P, Satterlee W, Sanger T, Hamilton S (1996). The Olanzapine HGAD Study Group. Olanzapine versus placebo and haloperidol: acute phase results of the North American double-blind olanzapine trial. Neuropsychopharmacol 14: 111-123.

Becquemont L, Verstuyft C, Kerb R, Brinkmann U, Lebot M, Jaillon $\mathrm{P}$ et al (2001). Effect of grapefruit juice on digoxin pharmacokinetics in humans. Clin Pharmacol Ther 70: 311-316.

Bhana N, Foster RH, Olney R, Plosker GL (2001). Olanzapine: an updated review of its use in the management of schizophrenia. Drugs 61: 111-161.

Boulton DW, DeVane CL, Liston HL, Markowitz JS (2002). Human recombinant $\mathrm{P}$-glycoprotein specificity for atypical antipsychotics. Life Sci 71: 163-169.

Boulton DW, Markowitz JS, DeVane CL (2001). Olanzapine assay by high performance liquid chromatography using ultraviolet detection. J Chromatogr 759: 319-323.

Carson SW, Ousmanou AD, Hoyler SL (2002). Emerging significance of P-glycoprotein in understanding drug disposition and drug interaction in psychopharmacology. Psychopharmacol Bull 36: 67-81.

Choo EF, Leake B, Wandel C, Imamura H, Wood AJ, Wilkinson GR et al (2000). Pharmacological inhibition of P-glycoprotein transport enhances the distribution of HIV-1 protease inhibitors into brain and testes. Drug Metab Dispos 28: 655-660.

Cordon-Cardo C, O’Brien JP, Casals D, Rittman-Grauer L, Biedler JL, Melamed MR et al (1989). Multidrug-resistance gene (Pglycoprotein) is expressed by endothelial cells at blood-brain barrier sites. Proc Natl Acad Sci USA 86: 695-698.

Cox DS, Scott KR, Gao H, Eddington ND (2002). Effect of P-glycoprotein on the pharmacokinetics and tissue distribution of enaminone anticonvulsants: analysis by population and physiological approaches. J Pharmacol Exp Ther 302: 1096-1104.

Dean M, Rzhetsky A, Allikmets R (2001). The human ATP-cassette (ABC) transporter superfamily. Genome Res 11: 1156-1166.

DeVane CL, Nemeroff CB (2001a). Clinical pharmacokinetics of quetiapine an atypical antipsychotic. Clin Pharmacokinet 40: 509-522.

DeVane CL, Nemeroff CB (2001b). Evaluation of risperidone drug interactions. J Clin Psychopharmacol 21: 408-416.

Eytan GD, Regev R, Oren G, Hurwitz CD, Assaraf YG (1997). Efficiency of P-glycoprotein-mediated exclusion of rhodamine dyes from multidrug-resistant cells is determined by their passive transmembrane movement rate. Eur J Biochem 248: 104-112.

Fricker G, Miller DS (2002). Relevance of multidrug resistance proteins for intestinal drug absorption in vitro and in vivo. Pharmacol Toxicol 90: 5-13.

Fromm MF (2000). P-glycoprotein: a defense mechanism limiting oral bioavailability and CNS accumulation of drugs. Int J Clin Pharmacol Ther 38: 69-74.

Germann UA (1996). P-glycoprotein-a mediator of multidrug resistance in tumour cells. Eur J Cancer 32A: 927-944.

Hennessy M, Kelleher D, Spiers JP, Barry M, Kavanagh P, Back D et al (2002). St Johns wort increases expression of Pglycoprotein: implications for drug interactions. $\mathrm{Br} \mathrm{J}$ Clin Pharmacol 53: 75-82.

Hoffmeyer S, Burk O, von Richter O, Arnold HP, Brockmoller J, Johne A et al (2000). Functional polymorphisms of the human multidrug-resistance gene: multiple sequence variations and correlation of one allele with P-glycoprotein expression and activity in vivo. Proc Natl Acad Sci USA 97: 3473-3478.

Kim RB, Fromm MF, Wandel C, Leake B, Wood AJ, Roden DM et al (1998). The drug transporter P-glycoprotein limits oral absorp- 
tion and brain entry of HIV-1 protease inhibitors. J Clin Invest 101: 289-294.

Kim RB, Wandel C, Leake B, Cvet Kovic M, Fromm MF, Dempsey PJ et al (1999). Interrelationship between substrates and inhibitors of human CYP3A and P-glycoprotein. Pharmaceut Res 16: 408-414.

Kroemer HK, Gautier JC, Beaune P, Henderson C, Wolf CR, Eichelbaum M (1993). Identification of P450 enzymes involved in metabolism of verapamil in humans. Naunyn Schmiedebergs Arch Pharmacol 348: 332-337.

Kurata Y, Ieiri I, Kimura M, Morita T, Irie S, Urae A et al (2002). Role of human MDR1 gene polymorphism in bioavailability and interaction of digoxin, a substrate of P-glycoprotein. Clin Pharmacol Ther 72: 209-219.

Letrent SP, Pollack GM, Brouwer KR, Brouwer KL (1999). Effects of a potent and specific P-glycoprotein inhibitor on the bloodbrain barrier distribution and antinociceptive effect of morphine in the rat. Drug Metab Dispos 27: 827-834.

Lin JH, Yamazaki M (2003). Role of p-glycoprotein in pharmacokinetics: clinical implications. Clin Pharmacokinet 42: 59-98.

Llorca PM, Coudore F, Corpelet C, Buyens A, Hoareau M, Eschalier A (2001). Integration of olanzapine determinations in a HPLCdiode array detection system for routine psychotropic drug monitoring. Clin Chem 47: 1719-1721.

Mahar Doan KM, Humphreys JE, Webster LO, Wring SA, Shampine LJ, Serabjit-Singh CJ et al (2002). Passive permeability and P-glycoprotein-mediated efflux differentiate central nervous system (CNS) and non-CNS marketed drugs. J Pharmacol Exp Ther 303: 1029-1037.

Markowitz JS, DeVane CL, Liston HL, Boulton DW, Risch SC (2001). Probenecid effects on the disposition of olanzapine and risperidone in healthy volunteers. Clin Pharmacol Ther 71: 30-38.

Nakamura T, Sakaeda T, Horinouchi M, Tamura T, Aoyama N, Shirakawa $\mathrm{T}$ et al (2002). Effect of the mutation (C3435T) at exon 26 of the MDR1 gene on expression level of MDR1 messenger ribonucleic acid in duodenal enterocytes of healthy Japanese subjects. Clin Pharmacol Ther 71: 297-303.

Perloff MD, von Moltke LL, Cotreau MM, Greenblatt DJ. (1999). Unchanged cytochrome P450 3A (CYP3A) expression and metabolism of midazolam, triazolam, and dexamethasone in $m d r(-/-)$ mouse liver microsomes. Biochem Pharmacol 57: $1227-1232$.

Polli JW, Wring SA, Humphreys JE, Huang L, Morgan JB, Webster LO et al (2001). Rational use of in vitro P-glycoprotein assays in drug discovery. J Pharmacol Exp Ther 299: 620-628.

Potschka H, Fedrowitz M, Loscher W (2001). P-glycoprotein and multidrug resistance-associated protein are involved in the regulation of extracellular levels of the major antiepileptic drug carbamazepine in the brain. Neuroreport 12: 3557-3560.

Potschka H, Fedrowitz M, Loscher W (2002). P-glycoproteinmediated efflux of phenobarbital, lamotrigine, and felbamate at the blood-brain barrier: evidence from microdialysis experiments in rats. Neurosci Lett 327: 173-176.

Ring BJ, Catlow J, Linday TJ, Gillespie T, Roskos LK, Cerimele BJ et al (1996). Identification of the human cytochromes P450 responsible for the in vitro formation of the major oxidative metabolites of the antopsychotic agent olanzapine. J Pharmacol Exp Ther 276: 658-666.

Riordan JR, Deuchars K, Kartner N, Alon N, Trent J, Ling V (1985). Amplification of P-glycoprotein genes in multidrug-resistant mammalian cell lines. Nature 316: 817-819.

Roberts RL, Joyce PR, Mulder RT, Begg EJ, Kennedy MA (2002). A common P-glycoprotein polymorphism is associated with nortriptyline-induced postural hypotension in patients treated for major depression. Pharmacogenom J 2: 191-196.

Roninson IB, Chin JE, Choi K, Gros P, Housman DE, Fojo A et al (1986). Isolation of human mdr DNA sequences amplified in multidrug-resistant KB carcinoma cells. Proc Natl Acad Sci USA 83: 4538-4542.

Sarkadi B, Price EM, Boucher RC, German UA, Scarborough GA (1992). Expression of the human multidrug resistance cDNA in insect cells generates a high activity drug-stimulated membrane ATPase. J Biol Chem 267: 4854-4858.

Schinkel AH, Mayer U, Wagenaar E, Mol CA, van Deemter L, Smit $\mathrm{JJ}$ et al (1997). Normal viability and altered pharmacokinetics in mice lacking mdr1-type (drug-transporting) P-glycoproteins. Proc Natl Acad Sci USA 94: 4028-4033.

Schinkel AH, Smit JJ, van Tellingen O, Beijnen JH, Wagenaar E, van Deemter L et al (1994). Disruption of the mouse mdr1a Pglycoprotein gene leads to a deficiency in the blood-brain barrier and to increased sensitivity to drugs. Cell 77: 491-502.

Schinkel AH, Wagenaar E, Mol CA, van Deemter L (1996). Pglycoprotein in the blood-brain barrier of mice influences the brain penetration and pharmacological activity of many drugs. $J$ Clin Invest 97: 2517-2524.

Schuetz EG, Beck WT, Schuetz JD (1996). Modulators and substrates of P-glycoprotein and cytochrome P4503A coordinately up-regulate these proteins in human colon carcinoma cells. Mol Pharmacol 49: 311-318.

Schwab D, Fischer H, Tabatabael A, Poli S, Huwyler J (2003). Comparison of in vitro P-glycoprotein screening assays: recommendations for their use in drug discovery. J Med Chem 46: 1716-1725.

Siddiqui A, Kerb R, Weale ME, Brinkmann U, Smith A, Goldstein $\mathrm{D}$ et al (2003). Association of multidrug resistance in epilepsy with a polymorphism in the drug-transporter gene ABCB1. $N$ Engl J Med 348: 1442-1448.

Silverman JA (2000). P-Glycoprotein. In: René L (eds). Metabolic Drug Interactions. Lippincott-Raven Press: Philadelphia, PA. pp 135-144.

Syed SK, Christopherson RI, Roufogalis BD (1996). Chlorpromazine transport in membrane vesicles from multidrug resistant CCRF-CEM cells. Biochem Mol Biol Int 39: 687-696.

Thompson JS, Koszdin K, Bernadsrs CM (2000). Opiate-induced analgesia is increased and prolonged in mice lacking $\mathrm{P}$ glycoprotein. Anesthesiology 92: 1392-1399.

Tiberghien F, Loor F (1996). Ranking of P-glycoprotein substrates and inhibitors by a calcein-AM fluorometry screening assay. Anticancer Drugs 7: 568-578.

Tsui LC, Donis-Keller H, Grzeschik KH (1995). Report of the second international workshop on human chromosome 7 mapping 1994. Cytogenet Cell Genet 71: 2-21.

Urbatsch IL, al-Shari MK, Senior AE (1994). Characterization of the ATPase activity of purified Chinese hamster P-glycoprotein. Biochemistry 33: 7069-7076.

Uhr M, Grauer MT (2003). abcb1ab P-glycoprotein is involved in the uptake of citalopram and trimipramine into the brain of mice. J Psychiatry Res 37: 179-185.

Uhr M, Holsboer F, Muller MB (2002). Penetration of endogenous steroid hormones corticosterone, cortisol, aldosterone and progesterone into the brain is enhanced in mice deficient for both mdrla and mdr1b P-glycoproteins. J Neuroendocrinol 14: 753-759.

Uhr M, Steckler T, Yassouridis A, Holsboer F (2000). Penetration of amitriptyline, but not of fluoxetine, into brain is enhanced in mice with blood-brain barrier deficiency due to mdrla P-glycoprotein gene disruption. Neuropsychopharmacology 22: 380-387.

Van Asperen A, van Tellingen O, Tijssen F, Schinkel AH, Beijnen $\mathrm{JH}$ (1999). Increased accumulation of doxorubicin and doxorubicinol in cardiac tissue of mice lacking mdrla P-glycoprotein. Br J Cancer 79: 108-113.

Verstuyft C, Strabach S, El-Morabet H, Kerb R, Brinkmann U, Dubert L et al (2003). Dipyridamole enhances digoxin bioavailability via P-glycoprotein inhibition. Clin Pharmacol Ther 73: 51-60. 
Von Moltke LL, Granda BW, Grassi JM, Greenblatt DJ (1999). Multiple site interaction of triazolam and ketoconazole in mice: role of P-glycoprotein. Clin Pharmacol Ther 65: 143.

Weiss J, Sven-Maria GD, Martin-Facklam M, Kerpen CJ, KetabiKiyanvash K, Haefeli WE (2003). Inhibition of P-glycoprotein by newer antidepressants. J Pharmacol Exp Ther 305: 197-204.
Yamazaki M, Neway WE, Ohe $\mathrm{T}$ et al (2001). In vitro substrate identification studies for P-glycoprotein-mediated transport: species difference and predictability of in vivo results. J Pharmacol Exp Ther 296: 723-735.

Yu DK (1999). The contribution of P-glycoprotein to pharmacokinetic drug-drug interactions. J Clin Pharmacol 39: 1203-1211. 